\title{
RUANG REFLEKSI DIRI
}

\author{
Jeremy Marshall ${ }^{1)}$, Alvin Hadiwono ${ }^{2)}$ \\ 1)Program Studi S1 Arsitektur, Fakultas Teknik, Universitas Tarumanagara, jeremy.marshall566@gmail.com \\ 2)Program Studi S1 Arsitektur, Fakultas Teknik, Universitas Tarumanagara, alvinhadiwono@ymail.com
}

Masuk: 10-01-2020, revisi: 28-01-2020, diterima untuk diterbitkan: 09-05-2020 (doi: 10.24912/stupa.v2i1.6873)

\begin{abstract}
Abstrak
Salah satu masalah yang umum saat ini adalah kurangnya tempat berkumpul Third Place yaitu tempat selain rumah (First Place) dan kantor (Second Place), sehingga Third Place dibuat sebagai tempat orang berkumpul, merasa tenang, dan terhindar dari kejenuhan kebiasaan sehari hari, yaitu first place dan second place isu yang ada saat ini dalam kegiatan sehari hari yang menyebabkan orang menjadi tidak produktif, yaitu masalah stress, tanpa kita sadari, saat ini masalah stress sudah dialami oleh siapa saja, tidak terpengaruh oleh umur, karena terdapat banyaknya faktor faktor pemicu stress, sehingga hal itu merupakan masalah yang dialami oleh semua orang, dan dapat menjadi salah satu target yang harus diatasi untuk menciptakan manusia yang memiliki pola hidup baik dan produktif dalam mengerjakan sesuatu, tujuan desain proyek ini sendiri juga dibuat untuk mengatasi isu global yang ada saat ini, dimulai dari kawasan yang paling merasakan pengaruh isu stress ini, karena memiliki banyak hal yang menjadi pemicu seseorang menjadi stress, hal ini dapat menciptakan proyek yang dapat menjadi tempat orang untuk berkumpul dan mengatasi isu stress yang mempengaruhi kehidupan ini secara bersama sama, isu stress ini juga dapat diatasi dengan cara mengubah penduduk yang mengalami stress untuk mengikuti program Well being atau kesejahteraan individu, menurut $C D C$ (Centers for Disease Control And Prevention), Well being dapat meningkatkan kesehatan jasmani dan rohani berdasarkan hasil dari kegiatan positif yang dilakukan oleh suatu individu atau kelompok yang terus menerus dilakukan, sehingga dapat memberikan dampak besar seperti kebiasaan seseorang yang akan melakukan kegiatan kegiatan yang baik, penerapan 5 ways to well being merupakan teori yang digunakan untuk memperbaiki kebiasaan hidup seseorang menjadi lebih baik, dan hal ini dapat dimaksimalkan dengan program yang berhubungan dengan aktivitas di alam berdasarkan buku The Tao of Architecture, metode yang digunakan juga berdasarkan metode tipologi, dengan cara menerapkan desain berdasarkan bentukan bentukan umum yang dapat menyenangkan, dan menenangkan untuk meredakan stress pengunjungnya, dan metode Spatial Relation yang digunakan untuk memberikan desain unik yang belum ada dari penggabungan bentukan bentukan pola healing, dengan pola bentukan yang menyenangkan. Oleh karena itu tempat Retreat dapat memberikan dampak kesan menyenangkan dan menarik masyarakat untuk melakukan kegiatan kegiatan positif untuk menjadikan penduduk menjadi memiliki hidup yang lebih baik. Tempat yang memiliki banyak unsur alam memiliki fungsi untuk menenangkan pikiran seseorang, sehingga pikiran seseorang dapat menjadi tenang.
\end{abstract}

\section{Kata kunci: alam; gaya hidup; retreat; stress; third place}

\section{Abstract}

One common problem today is the lack of a Third Place gathering place that is a place other than home (First Place) and an office (Second Place), so that Third Place is made as a place for people to gather, feel calm, and avoid the saturation of daily habits, namely first place and second place issues that exist today in daily activities that cause people to become unproductive, namely the problem of stress, without us knowing, now the problem of stress has been experienced by anyone, not affected by age, because there are many stressors, so that it is a problem that is experienced by everyone, and can be one of the targets that must be overcome to create people who have good lifestyles and productive in doing something, the design goals of this project itself are also made to address current 
global issues, starting from the region that is most affected by the issue of stress, because it has many things becoming a trigger for someone to become stressed, this can create a project that can be a place for people to gather and overcome the issues of stress that affect this life together, this stress issue can also be overcome by changing the stressed population to join the Wellbeing or welfare program individuals, according to the CDC (Centers for Disease Control and Prevention), Wellbeing can improve physical and spiritual health based on the results of positive activities carried out by an individual or group that is continuously carried out, so that it can have a big impact such as, the habits of someone who will do good activities, application of 5 ways to wellbeing is a theory used to improve one's life habits for the better, and this can be maximized with programs related to activities in nature based on the book The Tao of Architecture, the method used is also based on typology methods, by applying design based on common formations that can be fun, and soothing to relieve the stress of visitors, and the Spatial Relations method used to provide a unique design that does not yet exist from combining the formation of healing patterns, with a pleasant pattern formation. Therefore the Retreat can have a pleasant and interesting impact on the community to carry out positive activities to make the population have a better life. A place that has many natural elements has a function to calm a person, so that person can become calm.

Keywords: nature; lifestyle; retreat; stress; third place

\section{PENDAHULUAN}

\section{Latar Belakang Proyek}

Zaman yang semakin maju saat ini dimana banyak orang saling bekerja sama untuk melakukan sesuatu menjadi lebih maksimal, namun keadaan yang ada saat ini yaitu kurangnya tempat berkumpul, sehingga hal yang dibutuhkan oleh setiap orang saat ini adalah tempat berkumpul Third Place / Tempat berkumpul selain di rumah dan di tempat kerja untuk menenangkan kejenuhan yang dialami setiap orang yang terjadi akibat dari kurangnya tempat berkumpul atau tempat rekreasi lain selain di rumah dan di kantor. Masalah yang dapat terjadi akibat dari kurangnya tempat berkumpul adalah orang akan mengalami stress, akibat dari pengaruh individualisme yang semakin lama terbentuk dan terus berkembang. Dalam rentang masa kurang lebih 20 tahun terakhir, dunia ini telah menciptakan perubahan besar yang dianggap dari dampak perubahan globalisasi, jaman yang semakin berkembang memberikan dampak positif yang memudahkan manusia dalam mengerjakan sesuatu hal, namun hal itu juga menyebabkan pendidikan yang terus berkembang semakin sulit. Manusia harus dapat mengikuti perkembangan jaman yang pesat ini dengan cara mempelajarinya supaya dapat bertahan hidup dan tidak tertinggal di perkembangan jaman yang pesat ini. Dari masalah pendidikan yang semakin sulit ini, banyak para pelajar yang menjadi stress, dan tidak dapat mengikuti perkembangannya, sehingga hal itu dapat menyebabkan stress berat yang membuat pelajar ini menjadi depresi yang memungkinkan keinginan untuk mengakhiri hidup atau bunuh diri. Dari data kematian yang ada saat ini untuk usia muda,paling banyak adalah penyebab dari kematian karena stress berat yang dialami akibat dari tekanan perkembangan jaman yang begitu pesat, sehingga banyak usia muda yang mudah stress, dan ingin bunuh diri akibat dari pengaruh pendidikan yang terlalu cepat berkembang dan sulit untuk dimengerti oleh para pelajar yang ada saat ini. Selain dari pengaruh paling buruk yang akan terjadi ini, pengaruh stress juga dapat menyebabkan setiap orang menjadi tidak produktif dalam mengerjakan sesuatu, dan menyebabkan orang untuk males melakukan kegiatan, yang akhirnya menuju ke kemalasan yang menyebabkan orang menjadi pengangguran.

Menurut badan kesehatan dunia (WHO) (Ika, 2015), dari sekitar 32 juta penduduk, 3 dari 100 ribu penduduk yang tinggal di Jawa Tengah menderita gangguan kejiwaan, dan 19 dari 100 ribu penduduk lainnya menderita stress. Dan dari data statistik DKI Jakarta saat ini mencapai 9.5 juta jiwa, jumlah penduduk yang stress mencapai 1.33 juta jiwa (14 persen dari 9.5 juta jiwa), sementara stress mencapai kurang lebih 95000 - 285000 orang (13 persen dari 9.5 juta 
jiwa) (Hidayat, 2012). Direktur Bina Upaya Kesehatan Jiwa Kementerian Kesehatan, Eka Viora (2015) menjelaskan bahwa masyarakat di kota besar mengalami stress karena menghadapi beban dan tuntutan kerja, sedangkan di kota kecil karena persoalan ekonomi, seperti kemiskinan atau sulitnya mencari kerja. (Kompas, 2015). Hal tersebut merupakan fenomena yang terkait dengan stress di perkotaan ditambah dengan tata kota yang buruk, hingga penyakit kronis yang diderita membuat masyarakat menjadi mudah terpengaruh oleh stress.

Stress bisa memengaruhi produktivitas, meningkatkan keparahan penyakit, hingga memunculkan gangguan sosial para pekerja, individu cenderung stress akan banyaknya pekerjaan di kantor dan banyaknya deadline yang harus dikerjakan di kantor, hal tersebut dapat secara perlahan menimbulkan stress kepada pekerja. Wellness dapat memberikan pergeseran terhadap gaya hidup menjadi lebih baik.

Visi proyek ini bertujuan untuk menyediakan wadah yang dapat memenuhi dan mengontrol kesehatan yang mempengaruhi kesehatan menjadi lebih baik. Untuk mengatasi masalah kesehatan dengan cara menjaga kebiasaan makan, kegiatan yang dilakukan sehari hari diatur, dan membuat orang lain di sekitar juga menjadi bahagia merupakan salah satu cara membuat orang menjadi lebih baik, kaarena seseorang dapat memiliki pola hidup baik apabila sekitarnya memiliki pengaruh kegiatan yang membuat kegiatan yang baik.

\section{Urgensi Isu}

Isu masalah yang ada saat ini, yaitu penduduk yang memiliki sedikit tempat komunikasi dapat menimbulkan orang menjadi menyimpan masalah mereka sendiri tanpa menanyakan ke orang lain, sehingga pikiran dan kegiatan orang yang jarang berinteraksi ini menjadi stress dan akan menyebabkan tiap hal yang dilakukannya menjadi tidak produktif.

\section{Pertanyaan Penelitian}

- Masalah stress yang terjadi, akibat dari kurangnya interaksi sosial dan fasilitas tempat berkumpul

- Apa solusi agar masyarakat dapat teratasi masalah kurangnya interaksi sosial dan bagaimana cara mengatasi stress yang ada di kawasan industri

- Apa solusi program desain yang dapat mengatasi masalah stress dan faktor lingkungan yang menjadi pemicu penyebab pebyebab stress

\section{Batasan Masalah}

Masalah dibatasi pada solusi, tanggapan, penyelesaian terhadap isu gaya hidup masyarakat untuk memberikan tempat untuk berkumpul dan berinteraksi tanpa memandang sosial status tiap orang, sehingga semua menjadi sama rata, dan untuk mengatasi masalah global yang ada saat ini, yaitu masalah stress dengan cara program yang menggunakan alam.

\section{Tujuan Penelitian / Desain}

Tujuan penelitian dan perancangan untuk mengatasi masalah stress bagi penduduk sekitar, menyediakan tempat untuk berkumpul, berinteraksi, dan untuk menghasilkan proyek yang dapat membantu perkembangan dan produktivitas pada penduduk sekitar.

\section{KAJIAN LITERATUR}

\section{Karateristik Tempat Ketiga The Great Good Place - Ray Oldenburg (1989)}

Tempat ketiga merupakan tempat berkumpul untuk berbagi informasi umum dan penting yang menghubungkan berbagai budaya, dan berbagai jenis perkumpulan, tanpa memandang jabatan dan umur yang dimiliki seseorang, Tempat Ketiga digunakan untuk melayani kebutuhan manusia akan persekutuan yang tidak bergantung pada kapasitas suatu bangsa. Tempat ketiga merupakan tempat seseorang untuk bersantai, selain dari pengaruh tempat ke dua dan tempat pertama yang berupa kantor dan hunian. 
Delapan Karateristik yang menjelaskan ciri ciri Third Place, menurut Oldenburg (1989):

- Tempat yang netral: Pengunjung memiliki kehendak yang bebas untuk memilih ingin mengunjungi tempat publik atau tidak tanpa terikat suatu aturan dan berdasarkan jabatan, politik, hukum dan lainnya, serta pengunjung juga bebas memilih untuk pergi dan datang sesuka mereka tanpa terikat suatu aturan.

- Leveler (Tempat Leveling): Tempat ketiga tidak mementingkan status individu dalam suatu perkumpulan, tidak ada yang mementingkan status atau latar belakang seseorang, memungkinkan tempat itu memiliki rasa kesamaan, tidak ada syarat dan persyaratan yang mencegah pengunjung untuk mendatangi tempat ketiga.

- Percakapan adalah kegiatan utama: Interaksi antar orang merupakan kegiatan utama, kegiatan utama dapat dibuat apabila kegiatan itu berupa kebutuhan yang penting, dan dibutuhkan semua orang tanpa memandang sosial status seseorang, sebagai contoh adalah tempat gunting rambut, setiap orang membutuhkan untuk menggunting rambut, sehingga tempat gunting rambut dibutuhkan selain dari kantor dan rumah.

- Aksesibilitas dan Akomodasi: Tempat ketiga harus bersifat terbuka, mudah diakses, dan mengundang untuk yang membutuhkan tempat bersantai tanpa mengganggu aktivitas lain, dan semua penghuninya dapat merasakan kebutuhan mereka terpenuhi.

- Pengunjung Tetap: Tempat ketiga memiliki pengunjung tetap yang memberikan dan menghidupkan suasana area, memberikan ruang sesuai dengan kebutuhannya, dan mengatur sesuai dengan mood aktivitas yang sedang berlangsung, serta mengundang pengunjung lain sehingga ingin menuju ketempat ketiga, dan merasa diterima di ruang ketiga.

- Profil Rendah: Tempat Ketiga memiliki Karakteristik yang sehat dengan ciri ruang yang tanpa pemborosan atau kemegahan, dan memiliki perasaan sederhana, sehingga dapat menerima semua pengunjung tanpa melihat status seseorang.

- Ruang memiliki perasaan yang menyenangkan: Di ruang ketiga, semua percakapan tidak dibuat untuk menciptakan ketegangan dan permusuhan, namun tempat ketiga harus berupa tempat yang berfungsi untuk menghilangkan stress atau untuk merelaksasikan diri dengan cara dapat bermain main atau bersantai sesuai keinginan kita, tanpa ada aturan yang mengganggu kebebasan kita dalam beraktifitas.

- Memiliki sifat seperti rumah: Pengunjung akan memiliki perasaan hangat, tenang, dan terelaksasi yang sama seperti sedang berada dirumah, dan dapat bersenang senang sesuai keinginan mereka dengan bebas, dan seperti rumah sendiri.

\section{Stress}

Pengertian Stress menurut Santrock adalah respon individu terhadap keadaan atau kejadian yang memicu stress (stressor), yang mengancam dan mengganggu kemampuan seseorang untuk menanganinya, sedangkan menurut Sapuri Rafy, Stress adalah reaksi atau respon tubuh terhadap stressor psikososial (tekanan mental atau beban kehidupan), sehingga selain menimbulkan perubahan perilaku juga dapat menimbulkan perubahan pada tubuh, menurut Sarafino stress adalah suatu kondisi yang disebabkan oleh transaksi antara individu dengan lingkungan yang menimbulkan jarak antara tuntutan tuntutan yang berasal dari berbagai situasi dengan sumber sumber daya system biologis, psikologis, dan sosial seseorang.

Dampak stress pada umumnya, individu akan mengalami ketegangan, dan kesulitan dalam mengatur waktu kegiatannya, karena dari pengaruh stress akan memunculkan kecemasan, yang mengakibatkan sistem syaraf menjadi kurang terkendali, yang dapat mengakibatkan tekanan darah meningkat, dan darah dialihkan dari sistem pencernaan kedalam otot otot, sehingga produksi asam lambung akan meningkat, dan dapat menyebabkan mual, dan pengaruh dari stress yang berkepanjangan akan menyebabkan gagal ginjal yang akan menyebabkan stroke. 


\section{Five Ways to Well-being - Ruben S. Seetharamdo Ph. D.}

Five ways to well-being merupakan 5 hal yang dapat membuat seseorang menjadi memiliki hidup yang sejahtera, hal ini dapat terjadi apabila dilakukan secara menyeluruh, 5 program ini terdiri dari :

- Connect: Dalam menciptakan sesuatu yang menyenangkan, menghabiskan waktu lebih banyak dengan orang yang penting bagi kita.

Creative Space Merupakan tempat perkumpulan untuk merancang atau mendesain sesuatu dengan kerja sama yang baik. Hal ini dapat menjadi potensi penduduk sekitar untuk dapat saling berinteraksi dan menyelesaikan seseuatu bersama sama dengan baik.

- Keep Learning: Belajar dapat membiasakan seseorang untuk berpikir, dan memberikan rasa percaya diri yang tinggi, akibat dari kemampuan kita menjadi lebih besar untuk mengatasi stress.

Library Tempat yang di buat untuk merespon dari keadaan sekitar tapak yang terdapat Sekolah dan hunian yang membutuhkan fasilitas pendidikan untuk meluangkan waktu selain di rumah dan di sekolah.

- Be Active: Menjadi aktif bagus untuk kesejahteraan fisik dan mental, hal itu menjadi baik, karena kita merasa baik tentang diri kita sendiri dan dunia sekitar.

Sport merupakan salah satu sarana untuk menghilangkan stress, karena stress dapat terjadi apabila orang tidak banyak bergerak, yang akan menyebabkan aliran darah yang terhambat, sehingga orang tersebut akan menjadi malas atau kurang bersemangat, sehingga Olahraga yang diajurkan, yaitu berupa Senam, Jogging, dan basket, berdasarkan dari fasilitas yang paling banyak di sekolah sekitar kawasan.

- Give Others: Memberi sesuatu yang baik untuk tiap orang, berbagi dengan sesama, hal itu dapat memberikan perasaan puas yang akan dirasakan pemberi dan penerima, hal ini dapat berupa mengajarkan atau saling bekerja sama.

Communal Place / Tempat ruang berkumpul, akibat dari kurangnya tempat berinteraksi sosial, dan berkomunikasi dari kawasan, dapat menyebabkan stress bagi individu penduduk. Sehingga ruang communal penting untuk kawasan tapak.

- Take Notice: Memperhatikan sesuatu yang baik, menyadari tiap perasaan, melanjutkan hidup dengan cara yang dinginkan, merasakan berbagai indra dengan tenang.

Taman tempat untuk berinteraksi dan berkomunikasi melalui saling bertanam dan membagi hobi yang sama di kawasan sekitar tapak. Taman yang ada terdiri atas 2 jenis tanaman yang paling banyak dari data statistik di Kawasan Cakung, yaitu Tanaman Obat dan Tanaman Hias.

\section{METODE}

Metode pengumpulan data menggunakan metode studi literatur, studi kasus, survey lapangan, buku, dan data dari internet. Tahap desain dimulai dari isu, literatur, studi kasus proyek serupa baik luar negri dan dalam negri, program, survey lokasi, analisa lokasi baik makro hingga mikro, Arsitek terkenal, gubahan massa dipadukan dengan analisa lokasi, metode program memanfaatkan dari teori 5 ways to well being, sistem bangunan, dan detail.

Analisa lokasi dilakukan dengan cara pemetaan makro, meso, mikro, dalam mendesain gubahan massa, didesain berdasaarkan hasil program, analisa tapak, teori 5 ways to wellbeing, dan Prinsip desain Arsitek terkenal.

- Studi Kasus dan Studi Literatur

Metode yang digunakan pertama, yaitu dengan mengumpulkan isu dari latar belakang masalah yang terjadi pada masalah fatal yang ada di Indonesia melalui data dari berita dan urgensi masalah yang harus di selesaikan dalam waktu 30 tahun kedepan, di dukung dengan data data literatur dan penjelasan pengertian yang ada untuk membantu menyelesaikan masalah isu stress yang ada di Jakarta. 


\section{- Metode Tipologi}

Menurut Rossi dan Leon Krier, metode tipologi merupakan metode yang digunakan sebagai alat analisis yang akurat untuk bentuk arsitektur dan urban, yang juga menyediakan dasar rasional dalam desain. Hal yang menarik dalam tipe adalah bagian dari pencarian besar makna dalam era postmodern untuk menetapkan keberlanjutannya, dengan tujuan dapat mengembangkan perkembangan dari arsitektur yang sudah ada sebelumnya.

Metode tipologi digunakan dengan mengikuti desain yang sudah ada sebelumnya, namun lebih dikembangkan lagi sehingga dapat menyesuaikan kebutuhan arsitek yang ada saat ini, dan dapat menyesuaikannya dengan keadaan unik yang ada dikawasan, yang berbeda dengan desain lain yang pernah ada dibuat. Dari metode tipologi yang ada, kita dapat menentukan suatu desain melalui dari kegiatannya terlebih dahulu, yang merupakan suatu poin utama sebelum mendesain, metode tipologi dapat diperoleh berdasarkan analisa studi preseden, dan studi kasus dari proyek terkenal yang memiliki isu yang sama, di kondisi yang berbeda.

\section{- Metode Spatial Relation}

Metode spasial merupakan metode yang digunakan untuk mendapatkan informasi yang dipengaruhi oleh efek ruang dan bentuk permodelan, metode ini merupakan metode yang akan digunakan untuk mendapatkan bentuk gubahan massa, metode Spatial Relation merupakan metode yang terdiri dari bagaimana hasil dari bentuk yang dapat dikombinasikan dengan bentuk lain, dengan cara menambah dan mengurangi bentuk untuk menciptakan desain, dan menciptakan suasana ruang yang terjadi akibat dari penggabungan berbagai jenis bentuk, Metode ini dapat dicapai dari menggunakan metode Shape Grammar.

\section{DISKUSI DAN HASIL}

\section{Analisa Tapak}

Jakarta sebagai kota metropolitan memiliki masalah yang kompleks yang berhubungan dengan masalah kurangnya interaksi sosial yang menyebabkan setiap orang membutuhkan tempat ketiga. Tempat ketiga merupakan tempat yang diperlukan untuk setiap orang dapat berkomunikasi dengan siapa saja tanpa memandang status sosial mereka.

Berdasarkan dari masalah stress yang global saat ini, Lokasi yang merupakan paling tepat untuk mengatasi masalah yang akan memberikan dampak global, merupakan kawasan yang terkenal dengan kepadatannya, dari data populasi penduduk yang ada, Jakarta Timur merupakan kawasan dengan populasi terbanyak penduduknya. Dari data masalah stress yang ada saat ini, penyebabnya adalah kurangnya penanganan mental untuk penduduk di Jakarta, banyak dari penduduk yang malu untuk mengatakan sesuatu hal yang menyebabkan stress, sehingga banyak orang yang memendam masalah stress mereka secara sendiri, yang akhirnya menyebabkan keinginan bunuh diri. Pengaruh dari terhalangnya penduduk untuk mengunjungi pusat perawatan mental juga merupakan karena pengaruh dari sedikit nya fasilitas penanganan stress untuk therapy mental, dari data hal nya pengaruh penanganan mental stress, hanya 10 persen dari seluruh penduduk Jakarta yang mendapatkan layanan kesehatan mengenai stress.

$\begin{array}{ll}\text { Kode Blok } & : 13 \\ \text { Sub Blok } & : 001 \\ \text { Sub Zona } & : \text { K.1 } \\ \text { KDB } & : 50 \\ \text { KLB } & : 2.00 \\ \text { KDH } & : 30 \\ \text { KB } & : 4 \\ \text { KTB } & : 55\end{array}$

\author{
KDB : $2250 \mathrm{~m} 2$ \\ KLB : $9000 \mathrm{~m} 2(\max )$ \\ $\mathrm{KDH}: 1350 \mathrm{~m} 2$ \\ $\mathrm{KB}: 4$
}

KTB : $2475 \mathrm{~m} 2 \quad$ Luas Tapak : $4.500 \mathrm{~m} 2$ 


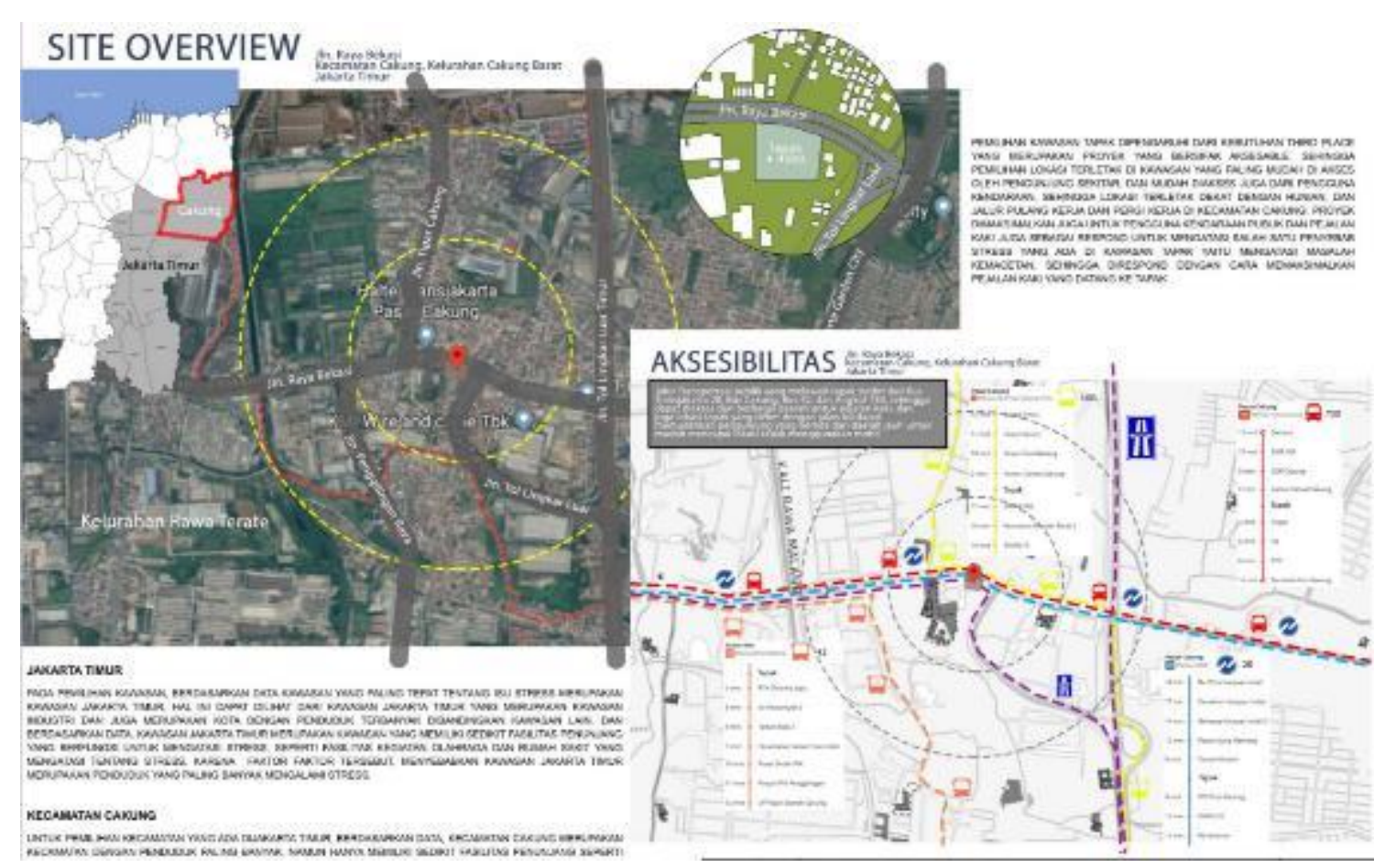

Gambar 1. Analisa Makro, Meso, Mikro

Sumber : Penulis, 2019

Tapak berada di Jalan Raya Bekasi, Kecamatan Cakung, Kelurahan Cakung Barat, Jakarta Timur zona perdagangan dan jasa kdb rendah, dan dikelilingi oleh kompleks perumahan, industri, dan bangunan komersial. Dengan area yang mudah diakses pejalan kaki, dan berada dekat dengan jalan tol, sehingga mudah diakses dari berbagai daerah Jakarta, dapat menghilangkan salah satu masalah penyebab stress, yaitu kemacetan dengan cara memaksimalkan pejalan kaki yang datang menuju ke bangunan.

\section{Aktivitas Program}

Program 5 ways to well-being penggabungan dengan alam untuk menarik perhatian penduduk sekitar untuk mengunjungi bangunan, dan menerapkan program kebiasaan yang baik untuk mengatasi mental stress penduduk sekitar kawasan. Hal ini dibagi dengan pembagian kebutuhan dan kapasitas ruang sesuai dengan kebutuhan penduduk sekitar dengan skala kelurahan. Dan 83 persen dari bangunan merupakan area Third Place atau ruang bertemu, sehingga dapat memaksimalkan area berinteraksi dan berkomunikasi pada kawasan Cakung Barat.

Fungsi bangunan yang dibutuhkan adalah program yang dapat menyatukan setiap orang, dengan cara membuat Area Creative Place, untuk para pengrajin kayu dan pelatih perkembangan kerajinan tangan dari penduduk yang tinggal di daerah tersebut, dengan memanfaatkan bahan bahan bekas yang masih dapat digunakan, sehingga dapat mengurangi polusi dari limbah industri. Gardening juga dapat digunakan untuk program di kawasan Cakung, karena dari data statistik yang menunjukkan bahwa daerah Cakung merupakan kawasan yang banyak tempat perdagangan, dan penanaman tanaman obat dan tanaman hias yang dapat berguna sebagai penanganan masalah polusi yang merupakan salah satu penyebab terjadi nya stress untuk penduduk yang tinggal dikawasan tersebut. 


\section{PROGRAM ACTIVITY}

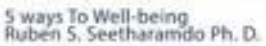

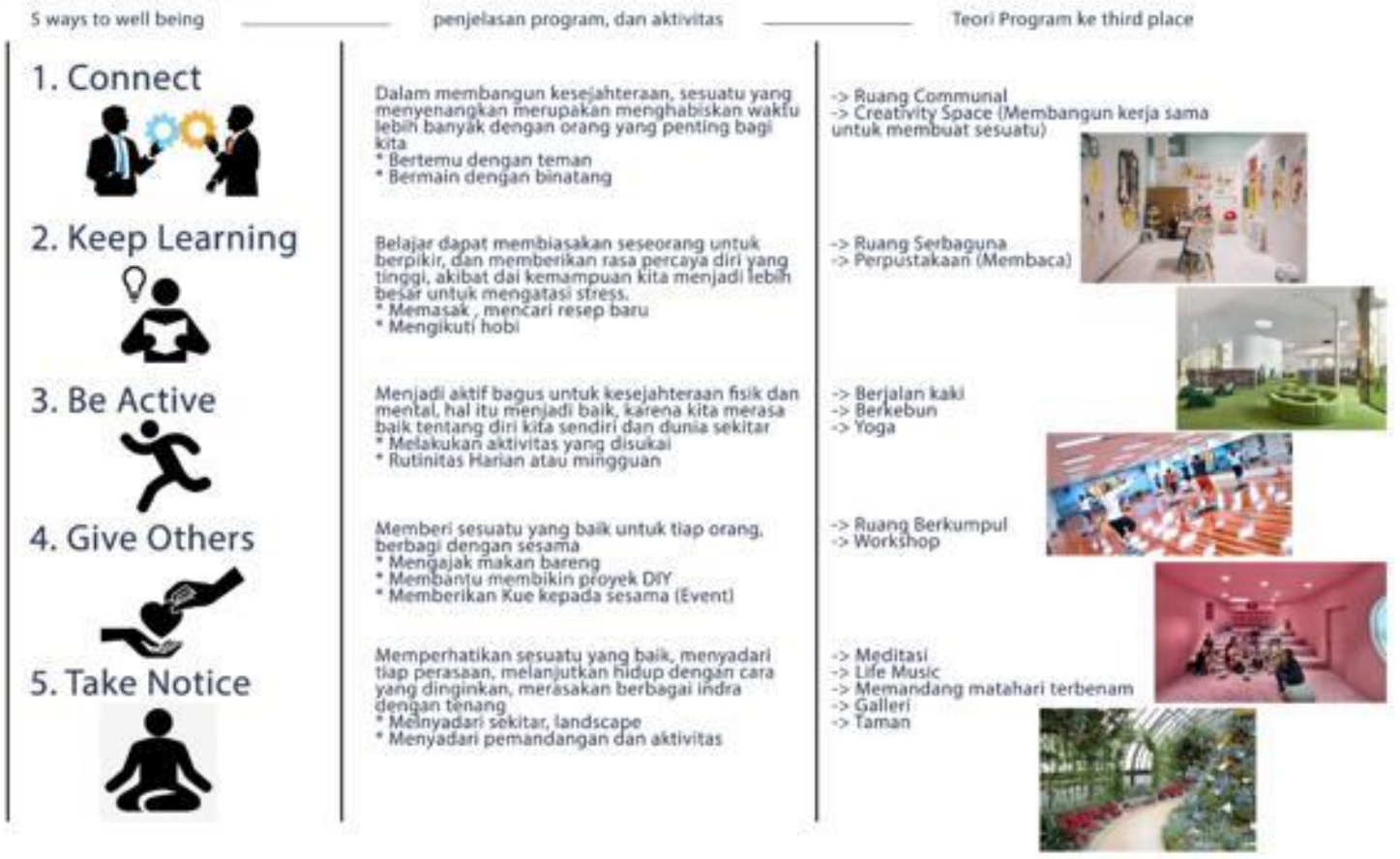

\section{PROGRAM RUANG}

\begin{tabular}{|c|c|c|c|c|c|}
\hline & 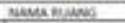 & Hes o waves & ovasian & Havey? & \multirow[t]{6}{*}{ 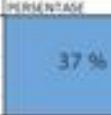 } \\
\hline \multirow{5}{*}{ Conthed } & 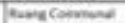 & 5000 & $\mathbf{m 0}$ & $=x+\infty$ & \\
\hline & Oneminty seaces & $1000 \mathrm{md}$ & 300 & $=\infty$ & \\
\hline & & $\infty \mathrm{ma}$ & 40 & 10 & \\
\hline & foost ine & 20001 & 100 & 0 & \\
\hline & & & $2100=2$ & & \\
\hline DEFIX & Dony sentions & $190 \mathrm{md}$ & 130 & 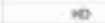 & \multirow{2}{*}{$4 \%$} \\
\hline & reprencest & $100 \mathrm{~m}$ & \pm 0 & $=0+4$ & \\
\hline \multirow{6}{*}{ actent } & & & & & \multirow{6}{*}{$25 \%$} \\
\hline & boerstinck & $230 \mathrm{mt}$ & 200 & $-\infty \infty$ & \\
\hline & & $\$ 00 \mathrm{mt}$ & $\mathbf{m o}$ & $=1+\infty$ & \\
\hline & Wes betianen & 200000 & $\%$ & $=\infty$ & \\
\hline & & $130=0$ & wo & $=\infty$ & \\
\hline & enosinen- & $150 \mathrm{ma}$ & $\infty$ & tituk & \\
\hline & & & & & \\
\hline om aners & woblosenter & $\infty 0000$ & $\cos _{0 \times 2}^{200}$ & 10 & $9 \%$ \\
\hline \multirow[t]{4}{*}{ Thas nonct } & mosent & 15000 & 100 & has & \multirow{4}{*}{89} \\
\hline & int Mask & $200 \mathrm{md}$ & 100 & 100 & \\
\hline & Gulet & 20000 & $1+\infty$ & nea & \\
\hline & & & $1 \times=2$ & & \\
\hline & 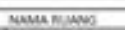 & 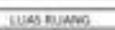 & Gevartas & shemen & ERESTAR \\
\hline \multirow[t]{5}{*}{ Mrasenes } & Tosenmonere & tom & 3 & * & \multirow{5}{*}{$2 \%$} \\
\hline & mavileat & $\infty=2$ & $n$ & $\infty$ & \\
\hline & Bareandeners & $\mathrm{nom}$ & as & 10 & \\
\hline & Donseneter & Dom & $n$ & no & \\
\hline & & & $120 \mathrm{me}$ & & \\
\hline \multirow{8}{*}{ Ares sentios } & & & 3 & 80 & \multirow{8}{*}{$4 \%$} \\
\hline & congun & $x \in=0$ & 5 & $\infty$ & \\
\hline & bescats & $20 \mathrm{~m}$ & s & w & \\
\hline & 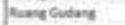 & som & so & 10 & \\
\hline & constiono & $200 \mathrm{ml}$ & 3 & 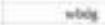 & \\
\hline & brevecter & som & 3 & $=1+4$ & \\
\hline & 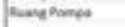 & $\operatorname{som}$ & 3 & then & \\
\hline & & & $100 \mathrm{~m}$ & & \\
\hline \multirow{3}{*}{ pons } & hebe mave & & no & & \multirow{3}{*}{$11 \%$} \\
\hline & 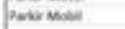 & $\infty 0000$ & 24 & $-\infty$ & \\
\hline & & & $1000 \mathrm{~m}^{2}$ & & \\
\hline
\end{tabular}

Gambar 2. Penerapan Program ke bangunan Sumber : Penulis, 2019
Diagram Persentase Program

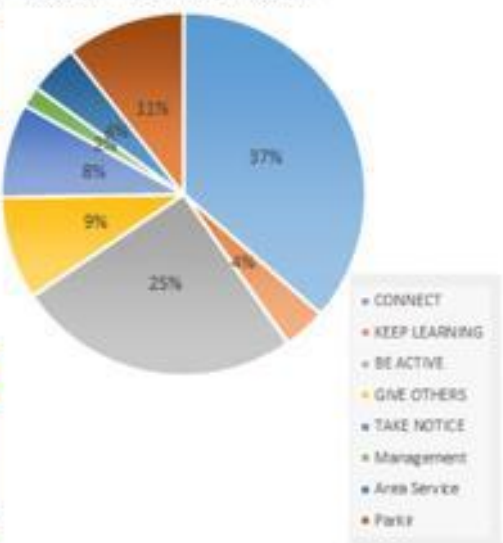

Diagram Persentase Third Place

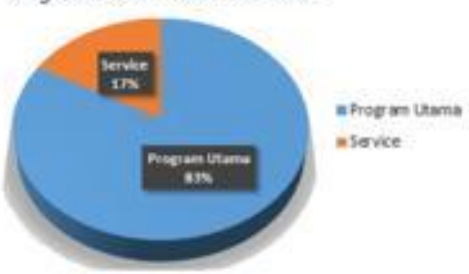

Perancangan ruang dalam memfokuskan kepada pengalaman pengalaman yang memberikan kesan ruang yang positif dengan cara penerapan kegiatan wellbeing dengan kegiatan di alam. 


\section{Analisis Konsep}

Berdasarkan metode tipologi, bangunan wellness berupa bangunan yang menyerupai bentukan bentukan alam, karena berdasarkan data dan analisa CNN tentang kesehatan, yang dapat mempercepat kesembuhan seseorang adalah pemikiran yang tenang dan relax, dengan hasil dari analisa, bahwa pasien yang berada dekat dengan jendela yang melihat ke pepohonan dapat mempercepat proses kesembuhan seseorang.

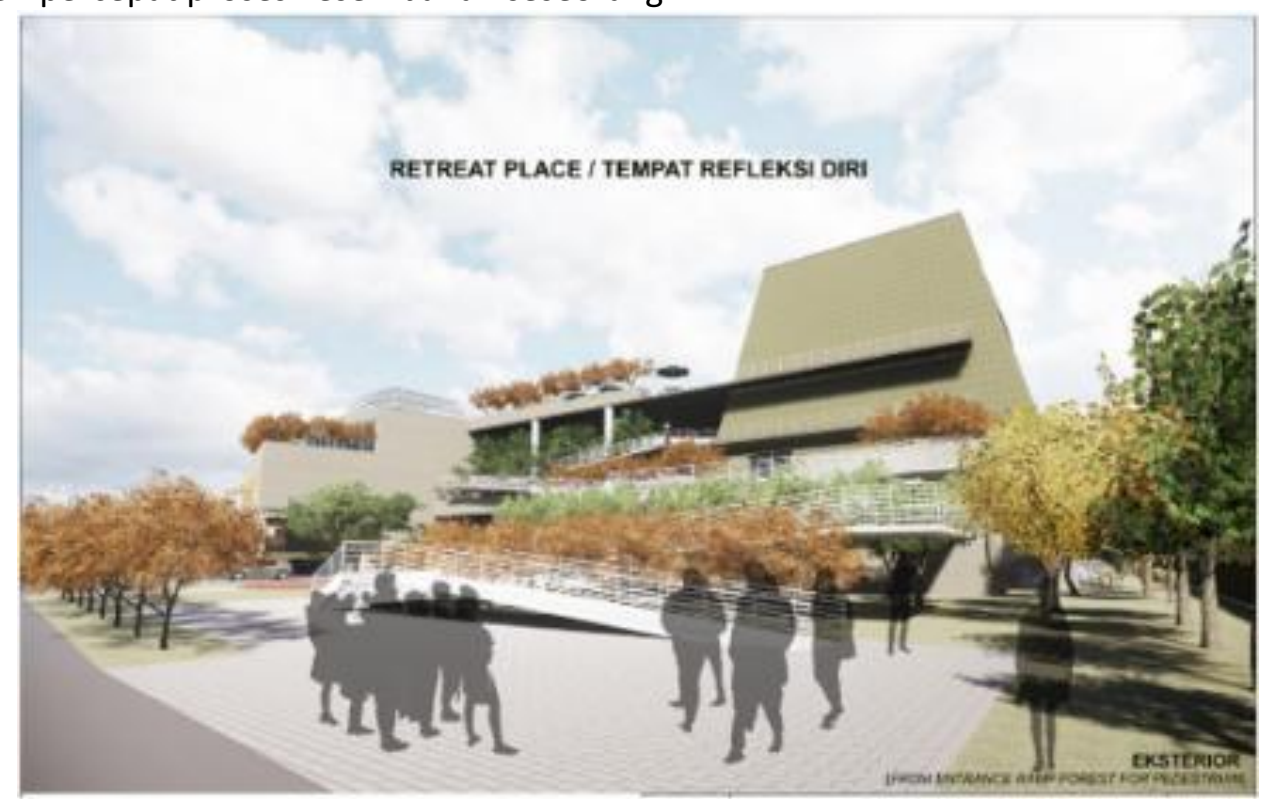

Gambar 3. 3D bangunan

Sumber : Penulis, 2019

Berdasarkan dari data studi preseden, proyek wellness pada umumnya berupa bentukan alam, dan dikelilingi pepohonan, serta memiliki banyak ruang berinteraksi dan berkomunikasi, sehingga dapat memberikan perasaan tenang, dan landscape yang mengikuti bentukan bangunan juga dapat mengatasi masalah stress dan third place .

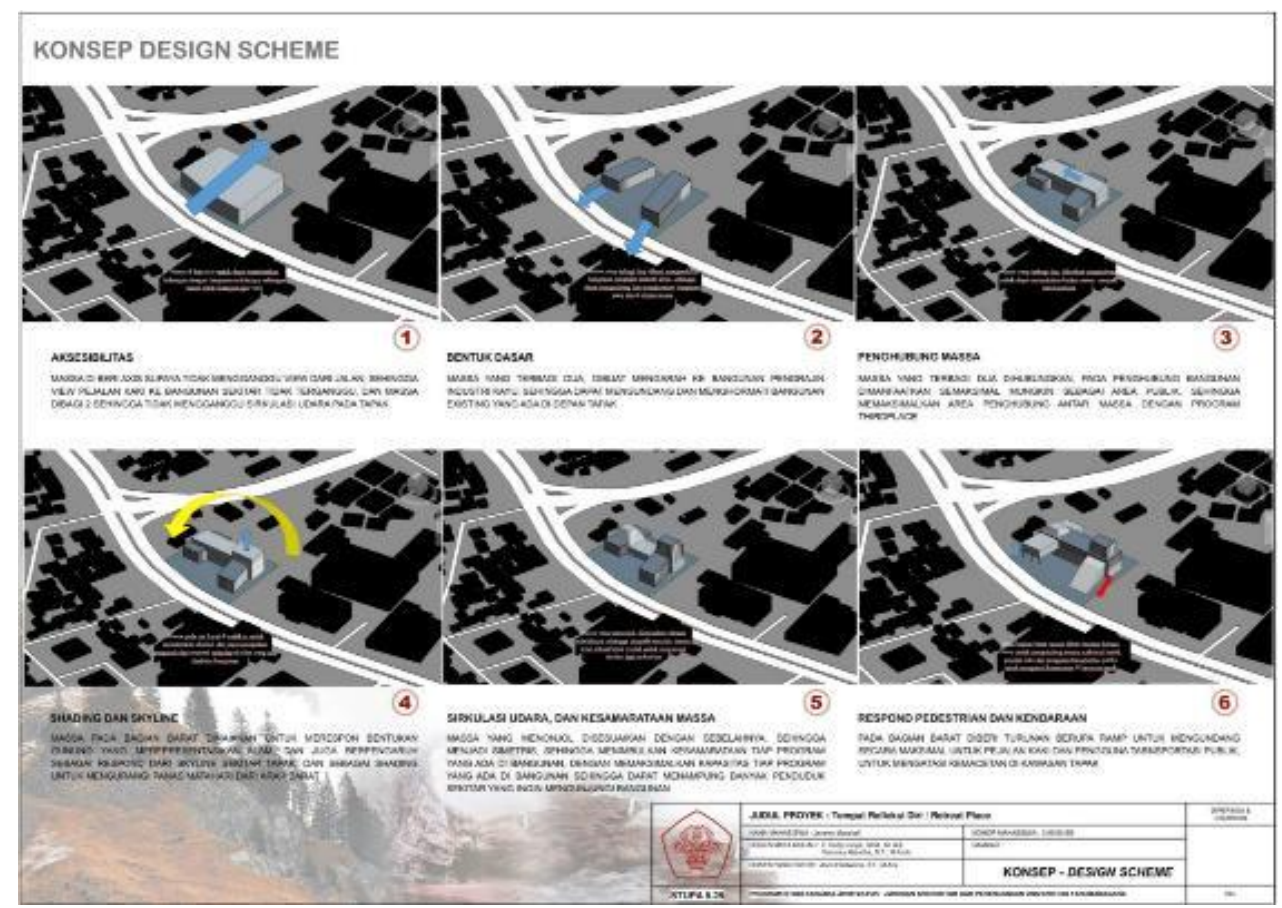

Gambar 4.Konsep Design Scheme

Sumber : Penulis, 2019 
Tahap awal yang dilakukan adalah dengan membagi aksis, supaya bangunan yang akan dibikin tidak mengganggu bangunan sekitar, dan massa dibagi dua supaya tidak mengganggu jalur sirkulasi udara, kemudian massa yang dibagi dua, dibuat mengarah ke bangunan industri kayu sebagai respond mengundang dan menghormati bangunan disekitar tapak, kemudian massa yang terbelah dua diberi konektifitas yang berupa massa baru yang berfungsi sebagai aktifitas penguhubung antara dua massa, yang digunakan sebagai tempat communal utama, kemudian bangunan sisi bagian barat di naiki sedikit sebagai shaded dan respond dari skyline sekitar bangunan, kemudian bentukan menonjol yang ada pada sisi barat disamakan, sehingga memberi kesan bahwa tiap program bersifat memanfaatkan secara maksimal, kemudian pada sisi barat, diberi bukaan pejalan utama, karena terletak disebelah halte bus, sedangkan sisi bagian timur diberi bukaan untuk undangan pengguna mobil dan kendaraan.
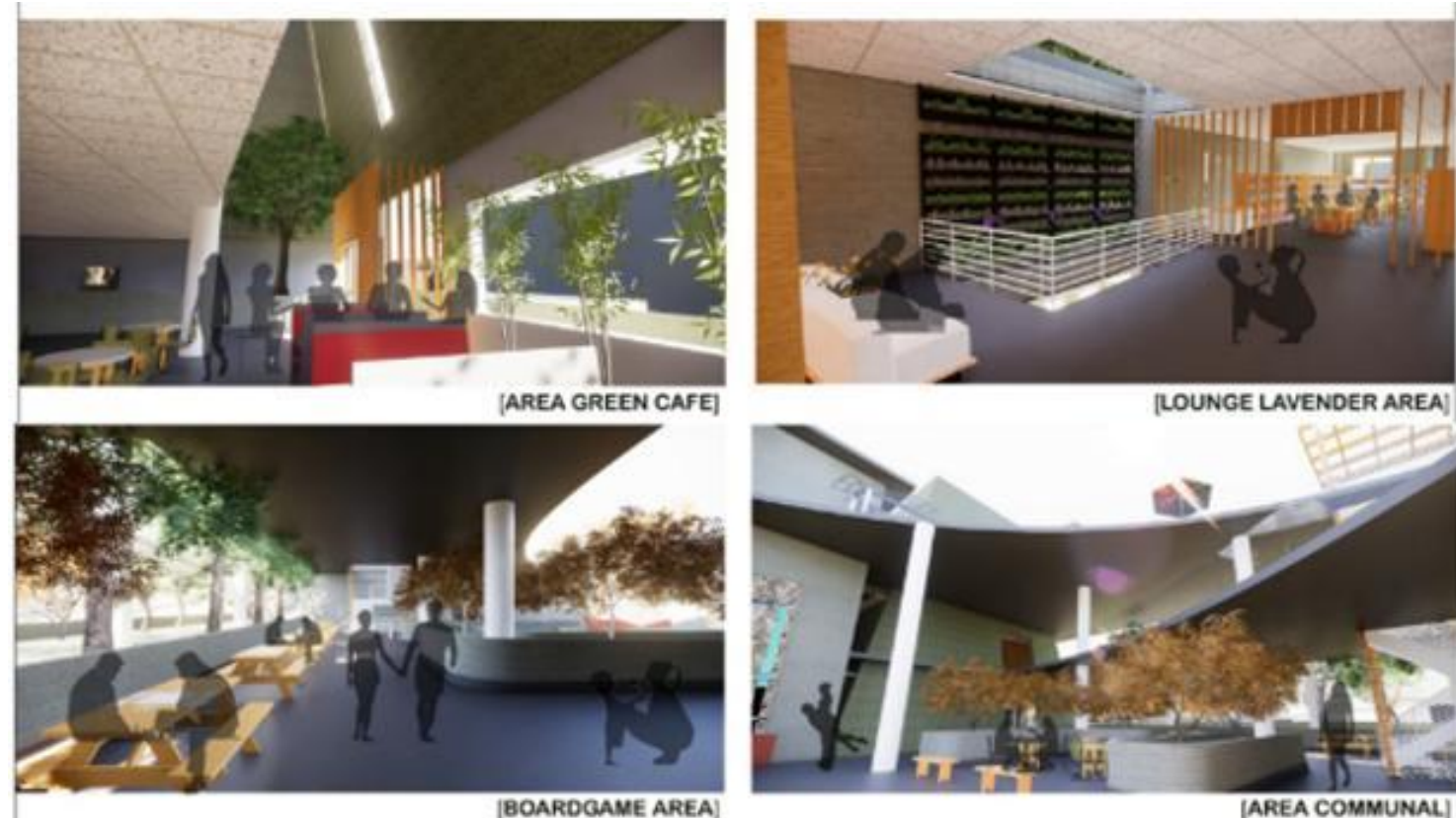

[BOARDGAME AREA]
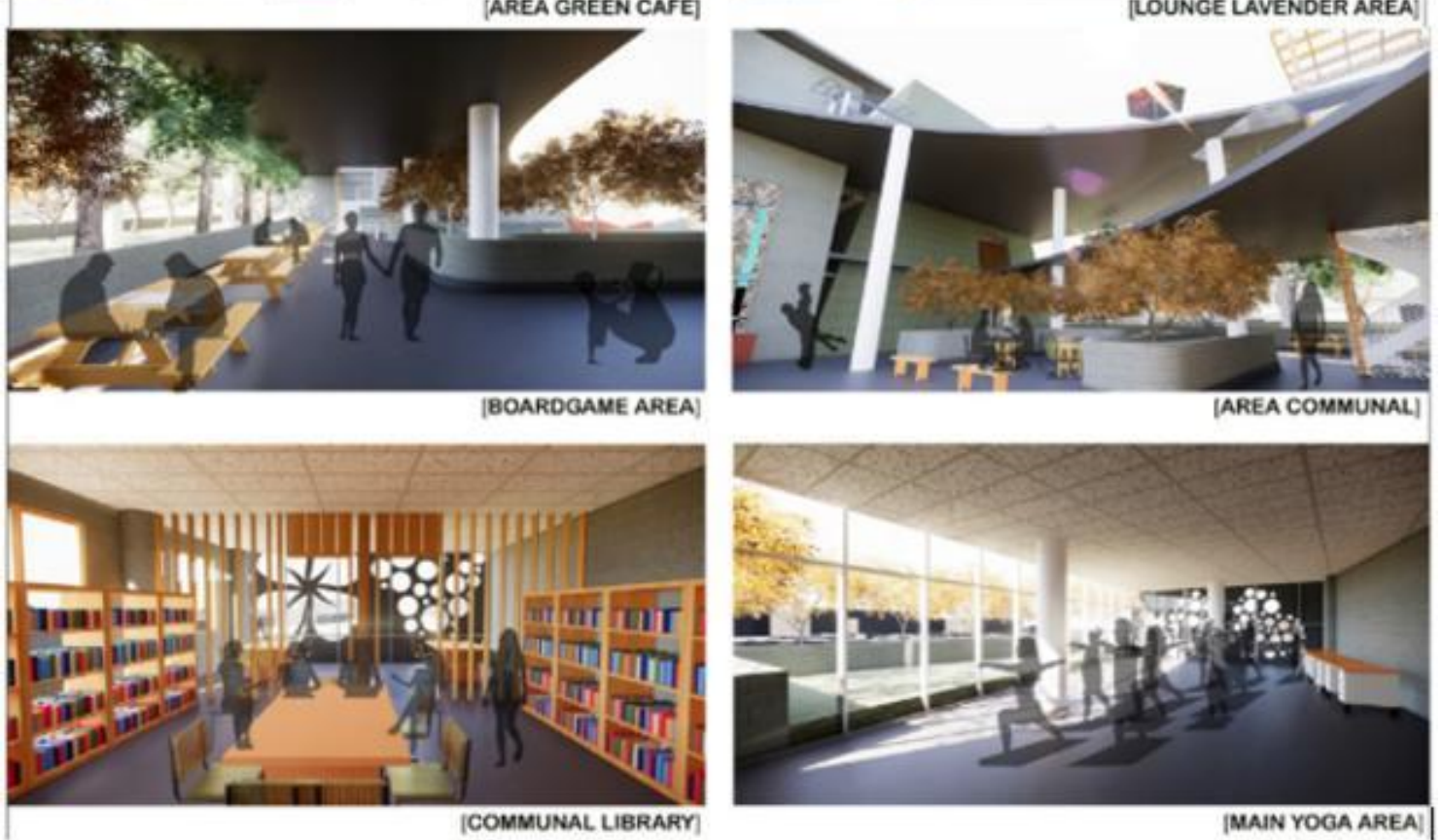

Gambar 5. Interior Design

Sumber : Penulis, 2019

Penerapan program bangunan yang bersifat aktivitas keluarga, berfungsi untuk memaksimalkan komunikasi antara keluarga, sehingga dapat memaksimalkan tingkat interaksi seseorang di dalam keluarga, dan dapat meningkatkan kualitas hidup seseorang. Dalam di tiap program bangunan juga diterapi alam, sehingga dapat memberikan kesan tenang dan menyenangkan saat berada di alam. 


\section{KESIMPULAN DAN SARAN \\ Kesimpulan}

Proyek yang dapat disimpulkan untuk mengatasi Stress, merupakan proyek sehat yang dapat merelaksasikan pengunjungnya, Proyek ini sendiri menargetkan pengunjungnya supaya dapat mudah untuk berinteraksi dan bersosialisasi, akibat dari sering berinteraksi adalah akan hilangnya kegiatan tindak kejahatan, karena tindak kejahatan sendiri juga dapat terjadi akibat pengaruh dari masalah Stress yang dialami oleh penderita. Penyebab stress sendiri itu dapat di sebabkan oleh beberapa faktor, seperti polusi, kemacetan, tingkat pendidikan yang kurang, fasilitas relaksasi yang sedikit, dan kurangnya bergerak dan beraktivitas dapat menjadi pemicu stress, karena itu untuk mengatasi stress, dapat berupa menyediakan semua fasilitas yang berfungsi untuk mengurangi masalah masalah yang ada di suatu kawasan, Oleh sebab itu, pemilihan proyek ini dimulai dari kawasan yang mengalami langsung faktor faktor pemicu stress, yaitu di lokasi Industri. Dari hasil proyek tersebut, diharapkan penduduk sekitar kawasan dapat memberi perilaku yang baik dan dapat mengurangi tindak kriminalitas di kawasan tersebut.

\section{Saran}

Sesuai dengan hasil evaluasi, program rekreasi dan relaksasi dapat meningkatkan kualitas hidup seseorang melihat dari pengaruh kehidupan buruk di sekitar yang ada saat ini dapat mempengaruhi seseorang menjadi stress, dan tidak produktif akibat dari kurangnya tempat untuk orang dapat berinteraksi dan berkomunikasi yang dibutuhkan dikawasan sekitar. Proyek ini dapat bermanfaat bagi masyarakat untuk meningkatkan kebiasaan kualitas hidup menjadi lebih baik.

\section{REFERENSI}

CNN Indonesia. (2018). Kesehatan jiwa dalam angka, diunduh 12 September 2019, dari: https://www.cnnindonesia.com/gaya-hidup/20181012194807-258-338084/infografiskesehatan-jiwa-dalam-angka.

Duncan, M. L., Jullan A. (2015). Sharing City: A Case for Truly Smart and Sustainable Cities. Massachusetts Institure of Techmology.

Jakarta Open Data. Data Jumlah Penduduk Berdasarkan Pekerjaan Per Kelurahan (2017), diunduh 13 September 2019, dari. http://data.jakarta.go.id/dataset/jumlah-pendudukdki-jakarta-berdasarkan pekerjaan/resource/1d4e7525-f975-4058-976c3563307126fe?inner_span=True

Marilu, V. (2008). Zest For Life : A Student Health And Wellness Centre [Skripsi]. South Africa(ZA) : University of Pretoria.

Oldenburg, R. (1989). The Great Good Place: Cafes, Coffee Shops, Community Centers, Beauty Partors, General Stores, Bars, Hangouts, and How They Get You Through the Day. New York: Paragon House.

Seetharamdo, R. (2018). 5 Ways to wellbeing, diunduh pada tanggal 28 Juli 2019, dari: https://www.fivewaystowellbeing.net/

Teori 5 ways to wellbeing, diunduh pada tanggal 29 Juli 2019, dari: https://www.mind.org.uk/workplace/mental-health-at-work/taking-care-of-yourself/fiveways-to-wellbeing/

Tjahjono, G. (2000). Metode Perancangan Suatu Pengantar untuk Arsitek dan Perancang. Depok: Universitas Indonesia.

White, E. T. (1987). Buku Sumber Konsep. Intermatra: Bandung.

Peraturan Daerah DKI Jakarta No.1 Tahun 2014 Tentang Rencana Detail Tata Ruang dan Peraturan Zonasi.

[Anonim]. 2014. Kesehatan Rohani di https://adapajaya.wordpress.com. Diakses pada tanggal 2 Januari 2019. 
